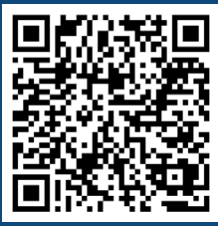

Keywords:

Multipurpose forest management

Management by objectives

Agroforestry systems

Dendroenergy

Allometric growth

Received 01/10/2019

Accepted 13/12/2019

+Correspondence:

javier_gyenge@yahoo.com
Javier Gyenge ${ }^{\mathrm{la}, 2+}$, Ana Lupi ${ }^{3}$, Paula Ferrere ${ }^{4}$, Germán Milione ${ }^{1,5}$, Alejandro MartínezMeier $^{6}$, Gonzalo Caballé ${ }^{6}$, Diego Dominguez Daguer ${ }^{7}$, María Elena Fernández ${ }^{1,2}$

\title{
STAND DENSITY MANAGEMENT DIAGRAMS OF Eucalyptus viminalis: PREDICTING STEM VOLUME, BIOMASS AND CANOPY COVER FOR DIFFERENT PRODUCTION PURPOSES
}

GYENGE, J.; LUPI, A.; FERRERE, P.; MILIONE, G.; MARTINEZ-MEIER, A.; CABALLÉ, G.; DAGUER, D. D.; FERNANDEZ, M. E. Stand density management diagrams of Eucalyptus viminalis: predicting stem volume, biomass and canopy cover for different production purposes. CERNE, v. 25, n. 4, p.463-472, 2019.

\section{HIGHLIGHTS}

A novel multipurpose management model for Eucalyptus viminalis was developed.

Simple equations were developed to estimate dominant height and tree canopy cover from stem diameter.

The model can estimate the wood production under different plantation density and thinning regimes.

The model allows management based on canopy cover for agroforestry system planning.

\section{ABSTRACT}

Stand density management diagrams (SDMD) provide a guide for forest density management taking into account stands attributes such as trees' diameter or volume. One of the most common species planted in Pampean plains of Argentina is Eucalyptus viminalis for multiple objectives: solid wood use or firewood in local markets, pulp for cellulose industry and to provide services for agriculture and cattle raising (windbreaks or cattle refuge). The objective of this study was to gather the available production information /inventory data and to develop a first SDMD for estimating standing volume, biomass and canopy cover of $\mathrm{E}$. viminalis as a tool for forest managers aiming at different plantation purposes. Data to develop the SDMD were obtained from $16 \mathrm{I}$ plots, distributed along a climate and soil gradient. We also generated two predictive equations capable of estimating dominant height from the diameter of the trees as well as canopy cover from stand basal area. As an example of application, the SDMD was used to estimate the wood production of three alternative systems: a) an unmanaged plantation (simulating a common practice in the region), b) a mixed production system such as an agroforestry system, and c) a plantation that maximizes wood biomass or volume production.

' Consejo Nacional de Investigaciones Científicas y Técnicas (CONICET), Buenos Aires, Argentina - ORCID: 0000$0003-3895-5112^{2}$

${ }^{2}$ AER Tandil, EEA Balcarce INTA, Buenos Aires, Argentina.

${ }^{3}$ Instituto de Suelos INTA, Castelar, Buenos Aires, Argentina

${ }^{4}$ AER 9 de Julio, EEA Pergamino INTA, Buenos Aires, Argentina.

${ }^{5}$ Instituto de Hidrología de Llanuras Dr. Eduardo Jorge Usunoff (IHLLA), Buenos Aires, Argentina 


\section{INTRODUCTION}

Several attributes of forests are related to the stocking of trees per unit land area (i.e. tree density), such as mortality or growth rate (current or mean annual increment), average size of the individuals (i.e. stem diameter) and other characteristics of the stand (i.e. canopy cover, carbon accumulation; Long and Vacchiano, 2014). These authors emphasize the relevance of estimating the boundary line that maximizes the combination of these attributes - density relationships. In the case of even-aged stands, intraspecific competition increases following the increase in tree size reaching a self-thinning situation. In this case, the increase in tree dimension depends on the decrease of the number of trees per unit area (Long et al., 2004). This kind of attribute -density relationship allows for foresters to develop stand density management diagrams (SDMD). These are average stand-level models that had been developed for a large number of species growing as pure or mixed stands, increasing their applicability following several objectives (Newton, 1997). The basic purpose of a SDMD is to easily guide the management of forest density taking into account stands attributes such as wood volume, canopy cover or biomass production, and also, the amount of energy provided by biomass or the potential pulp production (i.e. Pérez et al., 2008; PérezCruzado et al., 20I I; Tang et al., 2016).

Although these models are widely used worldwide, their development and implementation require large amounts of information, making them poorly available or even non-existent in some regions, particularly for species that have not been traditionally used for intensive wood production. This is the case of Pampa region of Argentina, South America, where agriculture and cattle raising are the main primary production activities. In this region, eucalypt silviculture is not as technologically advanced compared to intensive agriculture or to eucalypt silviculture in other regions of the country (i.e. North Eastern region) with a welldeveloped forestry sector. In this regard, there are no SDMD for anyof the forestry species cultivated in the Pampa region. The most common species planted in this region is Eucalyptus viminalis Labill (SINAVIMO, 2018). This species is widely distributed in Southeastern Australia, its provenance region, and is planted also in several countries of Africa showing a broad capacity to grow under different ecological constraints. As in its origin, in Pampa plains of Argentina it is cultivated under different soil and climate conditions. In this region, $E$. viminalis is grown between 600 and up to $1000 \mathrm{~mm}$ of mean annual precipitation. The highest growth rate occurs at the center of the region, reaching mean stem volume productivity of 35 to $40 \mathrm{~m}^{3} \cdot \mathrm{ha}^{-1} \cdot \mathrm{y}^{-1}$, decreasing this variable to the West due to water deficit, and to the East, because of the increase of waterlogging (SINAVIMO, 2018) associated with fine textured soils. In average, annual productivity is around $25-30 \mathrm{~m}^{3} \cdot \mathrm{ha}^{-1} \cdot \mathrm{y}^{-1}$, reaching 250-300 $\mathrm{m}^{3} \cdot \mathrm{ha}^{-1}$ of merchantable wood at the end of the rotation period (around 10-12 years; BA Buenos Aires Forestal 2010). Currently, the main destination of $E$. viminalis wood is for pulp use in a quite geographically distant cellulose industry due to its good kraft pulp quality (Neiva et al., 20l4), and in a minor degree, for solid use in local markets of products of low industrialization value. However, the species has a large potential for the production of veneer sheets and plywood panels (Iwakiri et al., 2013) and for direct structural solid use, increasing its economic value. Since the the regional economy is based on agriculture and cattle raising, it is common that forest stands are small, mainly smaller than I ha, with main or complementary objectives of providing cattle refuge, acting as windbreaks or providing firewood for the local residents (i.e. Mónaco and Laclau, 2013). At the same time, the potential for the development of silvopastoral systems as well as other agroforestry systems is currently being highlighted and promoted by different institutions (e.g. INTA, IPCVA, AFoA ) due to the need of innovative production systems that are more environmentally friendly, economically diversified and with a higher capacity of climate change mitigation than current agroecosystems.

Due to its high growth potential and adaptability, several trials have been installed analyzing differences in survival and growth of $E$. viminalis provenances from Australia and local Argentinean seed lots in different quality sites (Mendoza, 1974; Cappa et al., 2010). In addition, from samples of trees growing in a similar range of ecological situations, Ferrere et al. (20/4) have developed allometric models to estimate biomass of the leaves, branches and stems (with and without bark) of this species. In spite of this knowledge, there does not exist yet a compilation of this information in a SDMD type model to be available for both farmers and wood markets, allowing a rapid estimation of standing volume from inventory data (Schnell et al., 2012). Based on this, the objective of the present study was to gather the available production information and to develop a first stand density diagram for estimating standing volume, biomass and canopy cover of $E$. viminalis planted in the Pampas plains of Argentina. 


\section{MATERIAL AND METHODS}

\section{Study area}

The study was conducted in the Pampas plains, Buenos Aires Province, Argentina (Figure I). The climate of the region is humid temperate, with average annual temperatures of $14-15^{\circ} \mathrm{C}$, and annual average precipitation from $1000 \mathrm{~mm}$ in the East to less than $600 \mathrm{~mm} \cdot$ per.year $^{-1}$ in the West, evenly distributed throughout the year (Paruelo et al., 2007; Barros et al., 2013). This causes a water balance (precipitation minus evapotranspiration) gradient from positive or near zero in the NE area, to negative ( $-400 \mathrm{~mm}^{2}$ per year ${ }^{-1}$ ) in the SW area (Figure I). Regarding the soils, changes of depth and texture are observed, on an East-West direction, from relatively shallow loam clayey soils due to the presence of petrocalcic horizons (locally called "tosca") or rock, to sandy deep soils in the West (Paruelo et al., 2007).

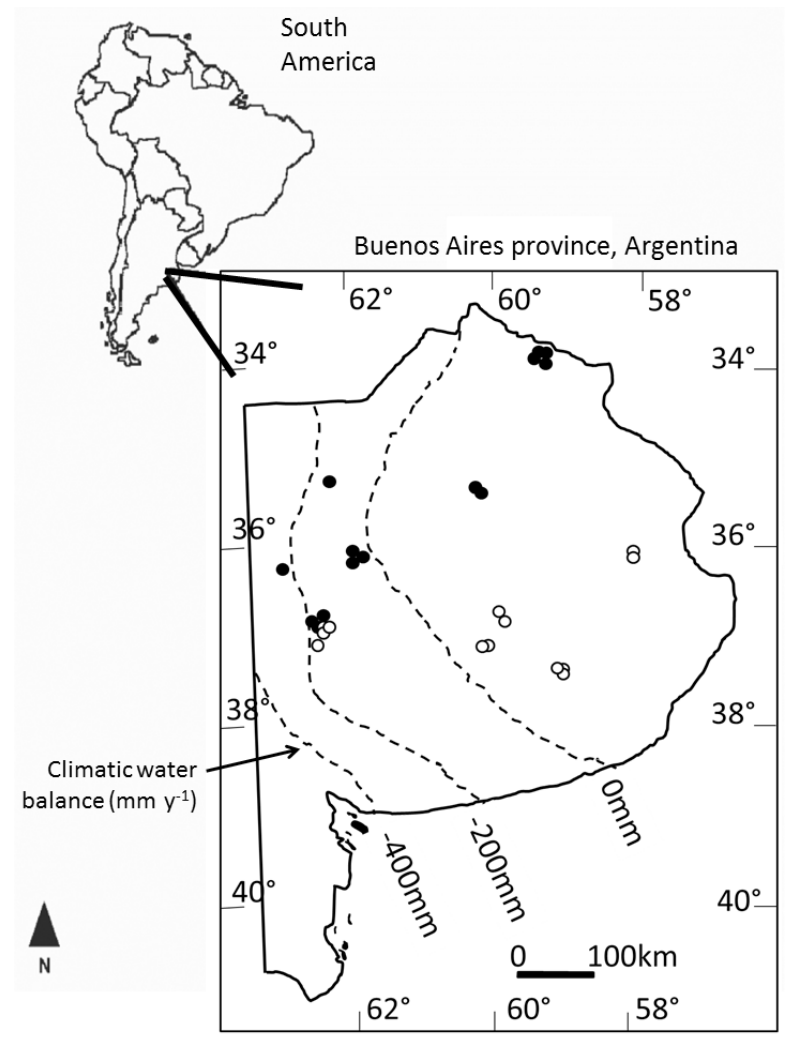

FIGURE I Study region showing the sites of the different Eucalyptus viminalis stands used to develop the SDMD (empty and filled dots). The climatic water balance $\left(\mathrm{mm} \mathrm{y}^{\prime}\right)$ was estimated as the difference between mean annual precipitations minus Penman-Monteith potential evapotranspiration (based on Nosetto et al., 2008). Empty dots represent the plots used to estimate the relationship between basal area and canopy cover (database from Milione, 2019; Figure 4).

\section{SDMD construction}

The data used to develop the SDMD were obtained from $16 \mathrm{I}$ plots, all established in Buenos Aires province (Figure I). Some of these data are unpublished (37 plots), but other come from the original database that supports the following publications: Caccia et al. ( $199 \mid$; $n=\mid 4$ plots), Ferrere et al. (2008; $n=22$ plots), Ferrere et al. (20l4; $\mathrm{n}=72$ plots), Milione (2019; $\mathrm{n}=16$ plots). Because some of these data were not digitalized before this study or the published articles or reports are written in Spanish, we include the data in the Appendix A. This database covers the main distribution of $E$. viminalis in Buenos Aires province and most of Pampa region: the northern plots were located near Paraná river (3335’31.20”S - 5952’3.58”O) meanwhile the Southern and Eastern plots were placed

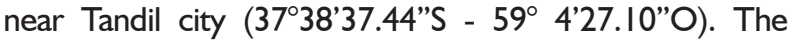
Western-most plots were located near Gral. Villegas city (3503'57.9”'S - 6252'02”O) (Figure I).

Quadratic mean diameter of each plot (Dq, $\mathrm{cm})$, dominant height $(H, m$, the height of the trees with highest $\mathrm{Dg}$ of the plot; criteria adopted by the authors of the databases Ferrere and Milione; see Appendix A) and number of trees per hectare $\left(\mathrm{N}\right.$, trees $\left.\cdot \mathrm{ha}^{-1}\right)$ were used as the basic variables to develop the SDMD. We use $\mathrm{Dg}$ and $\mathrm{N}$ data to develop SDMD of Caccia et al. (I99I), Ferrere et al. (2008, both in Appendix A) and Martínez Meier et al. and Lupi et al. (unpublished data), even if those databases lacked $\mathrm{H}$ values.

The measured stands covered a broad range of tree density (from 127 to 3680 tree $\cdot \mathrm{ha}^{-1}$ ) and sizes of the trees (mean $\mathrm{Dg}=10$ to $56 \mathrm{~cm}$; mean $\mathrm{H}=8$ to $33 \mathrm{~m}$; Table I). Some of the stands were harvested several times, meanwhile other had never received any intervention. From this set of stands, we followed the methodology proposed by Scharf et al. (1998) and Zhang et al. (2005) in order to objectively select those points situated in the upper boundary of $\mathrm{Dg}$ and $\mathrm{N}$ relationship for all available plots. For this purpose, three methods were applied. First, we manually chose those points considered as the limit of the relationship. As a second method, we divided the range of $\mathrm{Dg}$ into equal intervals (we chose 6 intervals) and selected the plot with the maximum $\mathrm{N}$ from each interval. Finally, as a third method, we applied a quantile regression (quantile 0.95 ). We selected 18 plots using the first method, 6 following the second method, and 7 for the quantile regression (third method). Some of these plots were selected by two or three methods applied. Finally, we adjusted the following equation to each dataset obtained from the applied methods. Where: $\mathrm{N}=$ tree density, trees. 
$\mathrm{ha}^{-1}, \mathrm{Dg}=$ quadratic mean diameter, $\mathrm{cm}, \mathrm{b}$ represent the exponent of Reineke's equation (equation 2), $a=$ $y$-intercept of the linear equation.

$\ln \mathrm{N}=\mathrm{a}-\mathrm{b} \cdot \ln (\mathrm{Dg})$

The adjusted model I using three methodologies of data selection were compared using $F$ tests with an $\alpha$ $=0.05$ (Neter and Wasserman, 1974).

TABLE I Characteristics of the plots used to develop the SDMD ( $\mathrm{n}=16 \mid$ distributed in the Pampas plain of Argentina, Figure l). SD = standard deviation; $\mathrm{N}=$ tree density; $\mathrm{Dg}=$ quadratic mean diameter at breast height; $\mathrm{H}=$ Dominant height; $\mathrm{VOLi}=$ tree individual volume, $\mathrm{VOL}=$ stand stem volume; $\mathrm{BIOM}=$ stand stem biomass; $\mathrm{G}=$ stand basal area; $\mathrm{Cov}=$ stand canopy cover.

\begin{tabular}{cccccc}
\hline Stand variable & Units & Average & SD & Max & Min \\
\hline $\mathrm{N}$ & tree $\cdot \mathrm{ha}^{-1}$ & 1046.2 & 543.4 & 3680 & 127 \\
\hline $\mathrm{Dg}$ & $\mathrm{cm}$ & 20.6 & 6.1 & 55.5 & 10.2 \\
\hline $\mathrm{H}$ & $\mathrm{m}$ & 22.0 & 5.0 & 32.8 & 7.9 \\
\hline $\mathrm{VOLi}$ & $\mathrm{m}^{3} \cdot \mathrm{tree}^{-1}$ & 0.21 & 0.16 & 1.40 & 0.01 \\
\hline $\mathrm{VOL}$ & $\mathrm{m}^{3} \cdot \mathrm{ha}^{-1}$ & 181.9 & 86.3 & 435.8 & 22.2 \\
\hline $\mathrm{BIOM}$ & $\mathrm{Mg} \cdot \mathrm{ha}^{-1}$ & 119.2 & 57.0 & 287.5 & 14.0 \\
\hline $\mathrm{G}$ & $\mathrm{m}^{2} \cdot \mathrm{ha}^{-1}$ & 31.2 & 12.8 & 79.1 & 5.7 \\
\hline $\mathrm{Cov}$ & $\%$ & 45.1 & 7.6 & 58.0 & 20.1 \\
\hline
\end{tabular}

Stand density index (SDI; Reineke, 1933) was estimated for each plot according to the following formula 2. Where: $b$ is the slope of equation I, 25 is the reference quadratic mean diameter, in $\mathrm{cm}$.

$\mathrm{SDI}=\mathrm{N}(\mathrm{Dg} / 25)^{\mathrm{b}}$

A dominant height - quadratic mean diameter relationship $(\mathrm{H}-\mathrm{Dg})$ was developed using data from IOI plots from the database provided by Ferrere et al. (20|4), Ferrere (unpublished data, $n=85$ plots), and Milione (2019, $\mathrm{n}=16$ plots). This dataset was divided into a modelling dataset and a validation dataset (50\% of the data on each). We adjusted the following model (i.e. Tang et al., 2016) taking into account that parameter c was adjusted to the data and not using a standard value of I.3:

$$
\mathrm{H}=\mathrm{c}+(\mathrm{Dg} /(\mathrm{d}+\mathrm{e} \mathrm{Dg}))^{3}
$$

For validation purposes, the goodness of fit and the prediction capacity of the models were evaluated through the coefficient of determination $\left(R^{2}\right)$, the observed versus predicted plot (with the line $y=\hat{y}$ marked), the mean absolute percent error (MA\%E $=100$

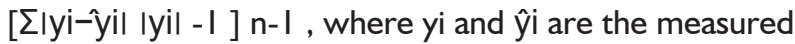
and estimated values), and a paired $t$ test (Mayer and Butler, 1993).

Forest canopy cover (COV, \%) was estimated from the analysis of flat photographs taken in the 14 plots described in Milione (2019) by means of ImageJ
I.48v program (Wayne Rasband, National Institutes of Health, USA). We used at least 5 photos per plot. The relationship between forest canopy cover (COV) and stand basal area $(\mathrm{G})$ and $\mathrm{Dg}$ was computed by means of a regression analysis. Stand basal area $(\mathrm{G})$ showed the best adjustment following (Table 2). Where: $f$ and $g$ correspond to the $y$-intercept and the slope, respectively, of the linear equation 4.

$\mathrm{COV}=\mathrm{f}+\mathrm{g} \ln (\mathrm{G})$

The adjustment of all the regression models was performed with Infostat statistical software (Di Rienzo et al. 20l3).

Application of SDMD for developing thinning schedules and yield estimation

As an example of use of the developed SDMD, we propose three different thinning schedules, based on tree density or canopy cover, each attempting to optimize different variables depending on different production objectives (Figure 2): A. Maximization of stem biomass production: thinning of $50 \%$ of the trees when the SDI reaches a value of $80 \%$ of the maximum SDI; $B$. Development of a mixed production system requiring solar radiation reaching the understory: managing tree density in order to maintain the canopy cover (COV) between 40 and 50\%; and C. No intervention (control situation). We considered two types of intervention: in the model A, we "harvested" the trees with the lower Dg reserving large trees (thinning from below). For this reason, the $\mathrm{Dg}$ of the stand increased following the trajectory of $\mathrm{H}$ (equation 3) because this last parameter is insensitive to stand density (i.e.Valbuena et al., 2008; Tang et al., 2016). On the contrary, in the model $B$, the objective of the management was to maintain light reaching the understory with a regular spatial distribution of the trees (systematic thinning). In this case, the thinning implied a spatially regular intervention, which resulted in no change in the average Dg of the stand (Figure 2). Finally, we assumed no natural mortality occurred between thinning treatments so size density trajectory was drawn parallel to $x$-axis. A similar assumption was also adopted to develop SDMD for other species (Valbuena et al., 2008).

\section{RESULTS}

Non-significant differences were found between the linear models describing the maximum relationship between $\ln \mathrm{N}$ and $\ln \mathrm{Dg}$ (eq [I]) using the three different data selection methods. Based on this, one model was adjusted using a combination of the data sets $(n=24)$. 


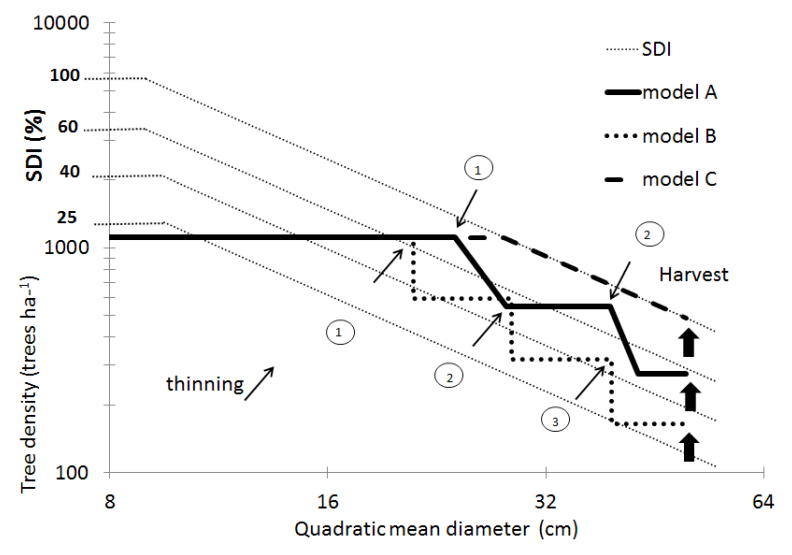

FIGURE 2 Stand density management diagram (SDMD) for Eucalyptus viminalis in Pampas plains, Argentina, including three examples of different types of thinning schedules (model $A$ : wood production optimization, thinning from below; B: mixed production system; systematic thinning; and C: unmanaged plantation, control) planned based on different production objectives. SDI = stand density index (SDI).

The slope of the linear relationship adjusted between $\ln \mathrm{Dg}$ and $\ln N$ was - I.425 (equation I in Table 2).

The parameters of the relationship between $\mathrm{H}$ and $\mathrm{Dg}$ (equation 3 ) were estimated with a high level of statistical significance $(p<0.000 \mathrm{I})$ presenting a relatively good goodness of fit $\left(R^{2}=0.796\right.$, Table 2$)$. The goodness of fit between the predicted and observed volume values was also high $\left(R^{2}=0.802\right)$. No bias was identified in the relationship between the observed $\mathrm{H}$ values (the validation dataset) and the estimated $\mathrm{H}$ using the equation 3 (Figure 3). MA\%E was low (8.36\%) and paired $\mathrm{t}$ test indicated no statistical differences between observed and estimated data.

Canopy cover increased following a nonlinear relationship from approximately $30 \%$ in those stands with basal areas lower than $20 \mathrm{~m}^{2} \cdot \mathrm{ha}^{-1}$ to reach maximum values around $60 \%$, when $G$ was around $50 \mathrm{~m}^{2} \cdot \mathrm{ha}^{-1}$, in spite of the different environmental conditions (Figure 4; Table 2, equation $4, R^{2}=0.802, p<0.00 I$ ).

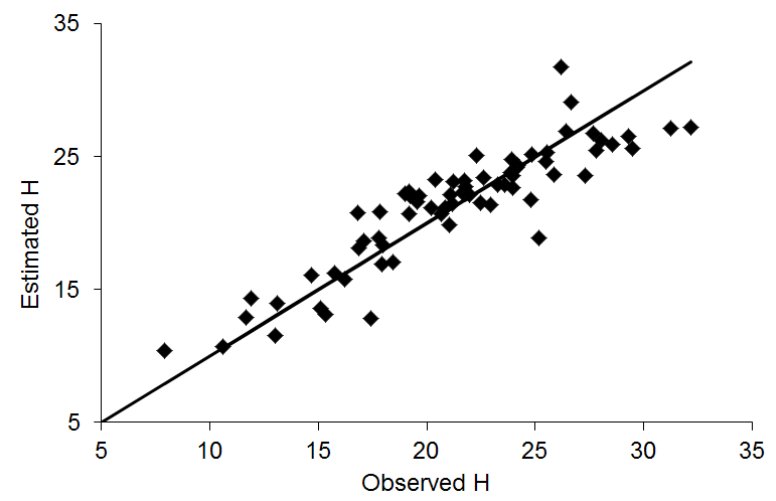

FIGURE 3 Relationship between observed and estimated H using equation 3 .

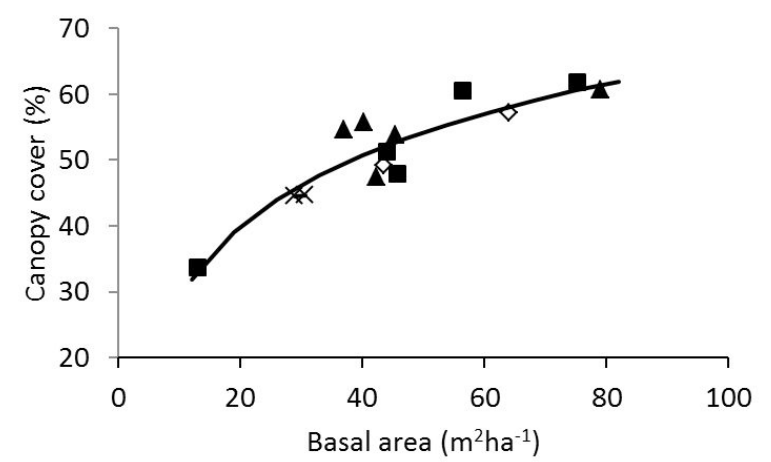

FIGURE 4 Relationship between basal area $\left(\mathrm{G}, \mathrm{m}^{2} \cdot \mathrm{ha}^{-1}\right)$ and stand canopy cover (COV, \%) of Eucalyptus viminalis in the Pampas plains described in Milione (2019). Different symbols denote the different sites corresponding to the empty dots in Figure I.

\section{SDMD Construction}

The first step in the construction of the SDMD was to fit the non-linear equations described in Table 2, relating stem volume without bark (VOL, $\left.\mathrm{m}^{3} \cdot \mathrm{ha}^{-1}\right)$, stem biomass (BIOM, kg.tree $\left.{ }^{-1}\right)$ and canopy cover (COV, \%) (Table 2). Taking into account the preceding equations (Table 2), Dg values were plotted in $\mathrm{x}$-axis vs. the number of trees.ha- ${ }^{-1}(\mathrm{~N})$ in the $y$-axis (logarithm scale). The isolines of stem volume [ VOL equation 4; Ferrere et al., 2008], stem biomass [BIOM equation 5 ; Ferrere et al., 2008] and canopy cover [COV equation 6] (Table 2) were presented by setting $\mathrm{Dg}$ constant and solving for $\mathrm{N}$ (Figure 5).

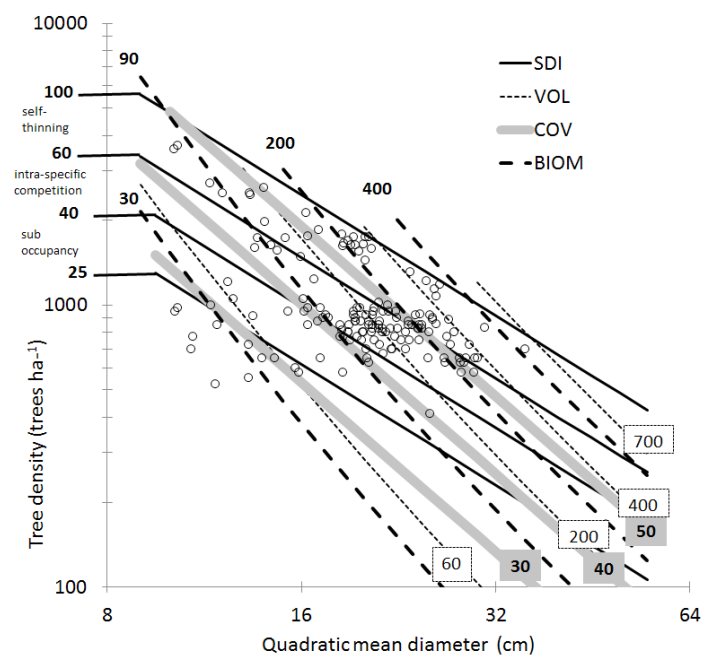

FIGURE 5 Stand density management diagrams (SDMD) for Eucalyptus viminalis in Pampas plains, Argentina. $\mathrm{SDI}=$ stand density index (eq.[2]), $\mathrm{VOL}=$ stem volume without bark, $\mathrm{m}^{3} \cdot \mathrm{ha}^{-1}, \mathrm{COV}=$ canopy cover, \%, BIOM= stem biomass, $\mathrm{kg} \cdot \mathrm{ha}^{-1}$. Empty dots represent the values of $\mathrm{Dg}$ and $\mathrm{N}$ measured in each plot. 
TABLE 2 Equations used to developed SDMD for Eucalyptus viminalis in Pampas plains, Argentina. Stem volume without bark (VOL, $\left.\mathrm{m}^{3} \cdot \mathrm{ha}^{-1}\right)$, stem biomass (BIOM, $\mathrm{kg} \cdot$ tree $^{-1}$ ), canopy cover (COV, \%), tree density (InN and $\mathrm{N}$, tree-ha $\left.{ }^{-1}\right)$ and dominant height $(\mathrm{H}, \mathrm{m})$. $\mathrm{RMSE}=$ Root mean square error.

\begin{tabular}{|c|c|c|c|c|c|}
\hline & Equation & $\begin{array}{c}\mathrm{R}^{2} \\
\text { adjusted }\end{array}$ & RMSE & Source & Equation \\
\hline VOL & $\begin{aligned} \ln (\mathrm{VOL})= & -10.333+0.99897 \ln (\mathrm{H})+ \\
& 1.9042 \ln (\mathrm{Dg})\end{aligned}$ & 0.99 & 0.1465 & $\begin{array}{c}\text { Ferrere } \\
\text { et al. } \\
(2008)\end{array}$ & [4] \\
\hline BIOM & $\begin{array}{c}\ln (\mathrm{BIOM})=- \\
.3539+1.3662 \ln (\mathrm{H})+1.7158 \ln (\mathrm{Dg})\end{array}$ & 0.99 & 0.115 & $\begin{array}{l}\text { Ferrere } \\
\text { et al. } \\
(2008)\end{array}$ & [5] \\
\hline $\mathrm{cov}$ & $\mathrm{COV}=-7.2156+15.695 \ln (\mathrm{G})$ & 0.80 & 10.867 & $\begin{array}{l}\text { This } \\
\text { study }\end{array}$ & [6] \\
\hline $\ln N$ & $\ln \mathrm{N}=11.560-1.425 \ln \mathrm{Dg}$ & 0.97 & 0.012824 & $\begin{array}{l}\text { This } \\
\text { study }\end{array}$ & [1] \\
\hline $\mathrm{H}$ & $\begin{array}{c}\mathrm{H}=-19.831+(\mathrm{Q} /(0.67569+ \\
0.25447 \mathrm{Dg}))^{3}\end{array}$ & 0.79 & $5.1|4|$ & $\begin{array}{l}\text { This } \\
\text { study }\end{array}$ & [3] \\
\hline
\end{tabular}

\section{DISCUSSION}

\section{Modelled relationships between stand variables}

The slope of the relationship between $\mathrm{N}$ and $\mathrm{Dg}$ was relatively high (less negative) compared with other species (slopes ranged between - I.63 and -2.00, Vospernik and Sterva 2015; or -1.47 to -2.24 in Condés et al., 2017), even compared to the value adopted as a universal constant (-I.605) estimated by Reineke (1933). Less steeped slopes of this relationship had been estimated for stands with a skewed diameter distribution (uneven-aged stands, Gül et al. 2005). In the present study, only stands of highest plantation density showed a skewed diameter distribution to the lowest diameter values (data not shown), probably influencing the observed slope value. In this regard, it has been proposed that fast-growing Eucalypts plantations present growth dominance after canopy closure, possible linked to their physiological plasticity (changes in resource use and resource use efficiency; Whitehead and Beadle, 2004; Fernández et al., 20I I), which could enhance size differences between the trees. Added to this, most of the studied plots lacked management, favouring high levels of intraspecific competition for resources and the expression of growth dominance. In this regard, Binkley et al. (2003) pointed out that in E. saligna monoculture, the largest $20 \%$ of the trees accounted for about half of the current wood growth. This marked growth dominance could result in skewed size distribution; however more effort is needed analysing the size distribution of the studied species under different environmental conditions and silvicultural management.

The strong relationship between COV and $\mathrm{G}$ in spite of the environmental differences between sites, at least in the annual water balance (Figure I), was similar with those described for E. grandis plantations in South
Africa. In this case, after canopy closure, the leaf area index in all density plantation density treatments converged to a similar level, that showed a slightly change in response to the soil water availability imposed by climate conditions ( $\mathrm{du}$ Toit, 2008). Based on this, the silvicultural management in a mixed production system, such as silvopastoril systems, could be easier than that developed with species reaching higher canopy cover due to their intrinsic higher shade tolerance. In this regard, the maximum leaf area index (leaf $\mathrm{m}^{2}$.per.ground $\cdot \mathrm{m}^{2}$ ) developed by Eucalyptus plantations under the best conditions of soil water availability and temperature reached 6 (Battaglia et al., 1998) against 12 in Douglas fir (e.g. Gyenge et al., 2009). With the exception of very young or very dense stands, the incomplete canopy cover of Eucalyptus plantations could be based on their intolerance to low irradiance and/or the fragility of their foliage (Schönau and Coetzee, 1989). In general, due to their leaf angles $\left(60-80^{\circ}\right.$ from the horizontal plane) and highly clumped leaf area, solar interception is lower in Eucalyptus spp forests than in other forests of similar height such as coniferous forests (Whitehead and Beadle, 2004).

Estimated maximum stand density index (SDI) was 1306, which represents the maximum number of stems per hectare for a reference diameter of $25 \mathrm{~cm}$ (equation 2). This value was close to 1210 , the value estimated for plantations of $E$. globulus (Reineke, 1933). We chose threshold values of 60 and 40 of SDI based on published information. In general, based on Long (1985), it is considered that $60 \%$ of maximum SDI is the lowest threshold of self-thinning, while a range around $25-35 \%$ of the maximum SDI represents the onset of competition and/or the full site occupancy. In the particular case of $E$. regnans, the lower limit to self-thinning was around $55 \%$, whereas $38 \%$ of maximum SDI corresponded to the maximum limit in which dominant trees showed a growth response to thinning (Goodwin, 1990). For E. grandis in Brazil, those limits corresponded with 55 and $45 \%$ of the maximum SDI, respectively (Marangon et al., 2017). However, because we do not have information about the mortality rate in $E$. viminalis, during the simulations we did not consider natural mortality between two thinning interventions, as indicated above. Full site occupancy and onset of competition for the development of management recommendations of $E$. viminalis from the SDMDs, are indicated as black filled lines in Figure 5.

Maximum SDI could change depending on environmental conditions and/or the particular responses to them of each species (Condés et al., 2017). These authors found that meanwhile the intercept and slope (in absolute value) in Pinus sylvestris were higher in the less 
humid areas compared to wetter ones, both parameters decreased in the more xeric sites in Fagus sylvatica. So in a particular environmental gradient, different species could present patterns of increasing or decreasing the parameters of the relationship between number-size of the trees. It is possible that maximum SDI may change in the Pampas plains of Buenos Aires, basically due to the different soil texture (from Clay to Sandy soils - e.g. Milione, 2019) and also, due to the gradient in water balance (Figure I) that limits the productivity of the stands (BA Buenos Aires Forestal, 2010, SINAVIMO, 2018). However, we do not have enough information to test the hypothesis that these environmental conditions lead to changes in this relationship, and only one general relationship has been applied to our whole data set. More effort is needed in order to calculate SDMD based on the particular environmental conditions of the sites.

Application of SDMD for developing thinning schedules and yield estimation

As an example of the applicability of the SDMD, we propose three different approaches outlined previously (Figure 2).

From the models, the maximum stem volume and biomass at the end of the production cycle was produced in Model C (no intervention), followed by Model A (thinning of $50 \%$ of $\mathrm{N}$ when SDI reached its $80 \%$ ) and $\mathrm{B}$ (managing the tree density in order to maintain COV between 40 and $50 \%$, Table 3 ). In this exercise, we determined the end of the cycle when the trees reached $50 \mathrm{~cm}$ of $\mathrm{Dg}$, but not considering the amount of years needed to reach that tree size. Model B needed 3 interventions (thinning) in order to maintain $\mathrm{COV}<$ $50 \%$ meanwhile Model A only two (Figure 4, Table 3). Model A produced around $96 \%$ and $98 \%$ of the VOL and BIOM, respectively, produced by the Model C (Table 3). Model $C$ provided the highest amount of trees with large Dg (Table 3). In the case of model B, that produced the lower amount of BIOM and VOL (69 and $70 \%$ of Model $\mathrm{C})$, we also have to consider the additional herbaceous yield (agriculture or animal forage), providing an annual income to the system (i.e. Ferreira et al. 20I2). On the other hand, it is expected that at higher relative densities (i.e. model C), individual tree leaf area, and thus tree growth, is much lower than that of open grown trees of the same species and age on the same site (Long et al., 2004). So, the time period that this stand needs to finish the cycle should be higher than in the other two models because the trees have lower mean annual increment compared to open stands. This was likely due to the fact
TABLE 3 Yield comparison of the three alternative management regimes derived from the SDMD based on three production models (A, B and $\mathrm{C}$, see text). $\mathrm{VOL}=$ total harvested stem volume without bark $\left(\mathrm{m}^{3} \cdot \mathrm{ha}^{-1}\right)$, $\mathrm{BIOM}=$ total harvested stem biomass $\left(\mathrm{Mg}^{\mathrm{h}} \mathrm{ha}^{-1}\right), \mathrm{Dg}=$ diameter at the breast height $(\mathrm{cm})$ of the harvested trees and $\mathrm{N}=$ number of trees harvested (trees haI). Columns I to 3 represent the estimated thinning interventions needed to reach each management goal.

\begin{tabular}{cccccc}
\hline $\begin{array}{c}\text { Thinning } \\
\text { interventions }\end{array}$ & 1 & 2 & 3 & 4 & TOTAL \\
\hline Model A & & & & & \\
\hline VOL & 119.2 & 243.6 & 522.3 & & 885.0 \\
BIOM & 88.9 & 174.6 & 360.7 & & 624.2 \\
Dg & 23.9 & 39.3 & 50.0 & & \\
Cover & 54.2 & 58.6 & 55.4 & & \\
N & 561 & 275 & 275 & & \\
\hline Model B & & & & & \\
\hline VOL & 123.2 & 143.4 & 172.3 & 313.4 & 632.8 \\
BIOM & 85.8 & 100.8 & 120.5 & 216.4 & 442.5 \\
Dg & 21.0 & 28.7 & 39.5 & 50.0 & \\
Cover & 50.1 & 50.1 & 50.4 & 47.4 & \\
N & 516 & 275 & 155 & 165 & \\
\hline Model C & & & & & \\
\hline VOL & 919.3 & & & & 619.3 \\
BIOM & 634.8 & & & & \\
Dg & 50 & & & & \\
Cover & 64.3 & & & & \\
N & 484 & & & & \\
\hline
\end{tabular}

that thinning is associated with increases in tree- and stand-growth efficiency (amount of wood produced by unit of leaf area) basically due to an increase of available resources to remaining trees, but also possibly due to an increase in light-use efficiency (Whitehead and Beadle, 2004). Finally, another alternative is to follow the model $C$ but harvesting all the trees when these reach the maximum size ( $100 \% \mathrm{SDI})$. In this case, trees reach a $\mathrm{Dg}$ of around $28 \mathrm{~cm}$, and the VOL and BIOM of the stand were around $604 \mathrm{~m} 3 \mathrm{ha}-\mathrm{I}$ and $425 \mathrm{~kg} \cdot \mathrm{ha}^{-1}$. This value was very close to those estimated for the stand with a higher SDI described in Milione (2019). The productivity of this alternative model is higher than the first intervention of the other proposed models (Table 3). For this reason, it is important to incorporate into any economic decision the rotation period in the unthinned alternative or model $\mathrm{C}$, which is longer than in the other options.

As we mentioned before, the time dimension is not considered in these diagrams, which can be assessed using site index curves if this information is available (e.g. Luis and Fonseca, 2004). Given the same initial density, stands on more productive sites will reach earlier the onset of competition, canopy closure, full site occupancy, and self-thinning than in less productive sites (Long et al., 2004). Unfortunately, there are no information about site index estimation for E. viminalis in Argentina, and we are unable to estimate any site index because the uncertainty about the age of a high proportion of the stands used to build the SDMD. 
Considering the energy provided by $E$. viminalis wood (gross calorific value of 15 and $19 \mathrm{MJ} \mathrm{kg}^{-1}$ with 20 15 and 5-0\% moisture, respectively; Pérez et al., 2008), the productive models evaluated estimate a range of 5 and $8 \mathrm{TJ} \mathrm{ha} \mathrm{ha}^{-1}$ at the end of the production cycle. This is higher than the average estimated for other species of Eucalypts or those reported for poplar or willow (Pérez-Cruzado et al., 20I I). These observations agreed with Pérez et al. (2008) who showed that the amount of energy produced by the genus Eucalypts is one of the greatest economic impact in the north of Spain.

Schönau and Coetzee (1989) have proposed that it is usually not economically justified to grow eucalypt plantations for the production of saw timber or other highly valued products unless the mean annual increment at 10 years is more than $30 \mathrm{~m} 3$ ha-lyear-I, or more than $20 \mathrm{~m} 3$ ha- Iyear-I at 20 years. Our estimations, and those provided by official forest-related sources (BA Buenos Aires Forestal 20I0; SINAVIMO 20I8), indicate that the $E$. viminalis afforestation in Pampa plains, even with the low genetic improvement of the planted materials, can reach wood volumes higher than 300 m3ha-I with average growth rates of $30 \mathrm{~m} 3 \mathrm{ha}-\mathrm{ly}-\mathrm{I}$, which gives an opportunity to provide both solid- and also pulpwood to the industry. However, more studies are needed focused on the response of the species, and of different provenances and genotypes within it, to the large environmental gradient present in the study region, as well on its response to silvicultural treatments such as pruning, thinning or fertilization.

\section{CONCLUSIONS}

The stand density management diagram (SDMD) developed for Eucalyptus viminalis afforestation in Pampa plains allows to estimate standing wood biomass and volume at the same time than canopy cover. It therefore provides a valuable tool to plan and evaluate alternative production systems based on the optimization of individual wood volume for solid wood industry, stand biomass for pulp or energy industries, or mixed production such as silvopastoral systems. The canopy cover component could also be used to plan open-canopy systems compatible with biodiversity conservation (e.g.Fiandino et al., 2018), lower water resources use (e.g.Licata et al., 20I I) and minimization of potential negative impacts on soils, such as secondary salinization (e.g. Nosetto et al., 2008). All these environmental aspects, added to the consideration of the proportion of wood products that goes into long-lived products and to energy production, could allow planning more sustainable production systems in the framework of current global challenges, such as climate change.

Notwithstanding this, more effort is needed in order to estimate a site index equation that allows the SDMD to estimate productivity (e.g. biomass per year) and rotation period, a key variable in any economic evaluation of different alternatives.

\section{ACKNOWLEDGEMENTS}

The authors thank the owners of the different afforestation in which we carried out all the field measurements. This work was supported by the Agencia Nacional de Promoción Científica y Tecnológica, MinCyT under Grant PICT 2013 I 223 Préstamo BID; and Instituto Nacional de Tecnología Agropecuaria under Grant PNFOR I I 04073, Argentina.

\section{REFERENCES}

BA BUENOS AIRES FORESTAL. 20I0. Revista Forestal, Ministerio de Agroindustria de la Provincia de Buenos Aires. Available online at http://www.maa.gba.gov.ar/2010/ SubPED/Agricultura/archivos/BAForestal_Revista; last accessed Apr. 12, 2018

BARROS, V.; VERA, C.; AGOSTA, E.; ARANEO, D.; CAMILLONI, I.; CARRIL, A.; DOYLE, M.; FRUMENTO, O.; NUÑEZ, M.; ORTIZ DE ZÁRATE, M. I.; PENALBA, O.; RUSTICUCCI, M.; SAULO, C.; SOLMAN, S. Cambio climático en Argentina; tendencias y proyecciones. Centro de Investigaciones del Mar y la Atmósfera. Vol. 2 y 5.20 I 3.

BATTAGLIA, M.; CHERRY, M.L.; BEADLE, C.L.; SANDS, P.J.; HINGSTON, A. Prediction of leaf area index in eucalypt plantations: effects of water stress and temperature. Tree Physiol v.18, p.521-528, 1998.

BINKLEY, D.; SENOCK, R.; BIRD, S.; COLE, T.G. Twenty years of stand development in pure and mixed stands of Eucalyptus saligna and nitrogen-fixing Facaltaria moluccana. For. Ecol. Manage. V. 182, p.93-102, 2003

CACCIA, F.; GARAU, A.M.; GUARNASCHELLI, A.B. Evaluación de la densidad actual en plantaciones de Eucalyptus viminalis por medio el índice de la densidad del rodal (Reineke) (Primer aporte). Jornadas sobre Eucaliptos de Alta Productividad. Buenos Aires (Argentina). 5-6 Dic 199I

CAPPA, E.P.; PATHAUER, P.S.; LOPEZ, G.A. Provenance variation and genetic parameters of Eucalyptus viminalis in Argentina. Tree Gen.Genom., v. 6, p.98I-994., 2010

CONDÉS, S.; VALLET, P.; BIELAK, K.; BRAVO-OVIEDO, A.; COLL, L.; DUCEY, M.J.; PACH, M.; PRETZSCH, H.; STERBA, H.; VAYREDA, J.; DEL RÍO M. Climate influences on the maximum size-density relationship in Scots pine (Pinus sylvestris L.) and European beech (Fagus sylvatica L.) stands. For. Ecol. Manage. V. 285, p. 295-307, 2019. 
DI RIENZO, J.A.; CASANOVES, F; BALZARINI, M.G.; GONZÁLEZ, L.; TABLADA, M.; ROBLEDO, C.W. InfoStat versión 2013. Grupo InfoStat, FCA, Universidad Nacional de Córdoba, Argentina. URL http://www.infostat.com.ar

DU TOIT, B. Effects of site management on growth, biomass partitioning and light use efficiency in a young stand of Eucalyptus grandis in South Africa. For. Ecol. Manage. v.255, p.2324-2336, 2008.

FERNÁNDEZ, M.E.; FERNÁNDEZ TSCHIEDER, E.; LETOURNEAU, F; GYENGE, J.E. Why do Pinus species have different growth dominance patterns than Eucalyptus species? A hypothesis based on differential physiological plasticity. For. Ecol. Manage. v.26I, pl06I-1068, 20 I I.

FERRERE, P.; LUPI, A.M.; BOCA, R.; NAKAMA, V.; ALFIERI, A. Biomasa en plantaciones de Eucalyptus viminalis Labill. de la provincia de Buenos Aires, Argentina. Ciência Florestal v. I8, p.29I-305, 2008.

FERRERE, P.; LUPI, A.M.; BOCA, R.T. Estimación de la biomasa aérea en árboles y rodales de Eucalyptus viminalis Labill. Rev. Quebracho v.22, p. I00-II3, 2014.

FERREIRA, A.D.; ALMEIDA, R.G.; MACEDO, M.C.M.; LAURA, V.A.; BUNGENSTAB, D.J.; MELOTTO, A.M. Arranjos espaciais sobre a produtividade e o potencial de prestação de serviços ambientais do eucalipto em sistemas integrados. In: congresso latinoamericano de sistemas agroflorestais para a produção pecuária sustentável, Belém, PA. Belém, PA: CATIE; CIPAV, Brazil. p. I-5.20I2.

FIANDINO, S.I.; PLEVICH, J.O.; TARICO, J.C.; NUÑEZ, C.; RUSCH, V.; GYENGE. J. Effects of low-density Pinus elliotti (Slash pine) afforestation on environmental conditions and native plants diversity, in the mountains of central Argentina. Applied Vegetation Science v.2I p.442-450, 2018.

GOODWIN, A. Thinning response in eucalypt regrowth. Tasforests v.2, p. 27-35, 1990.

GÜL, A.U.; MISIR, M.; MISIR, N.; YAVUZ, H. Calculation of uneven-aged stand structures with the negative exponential diameter distribution and Sterba's modified competition density rule. For. Ecol. Manage. v.2 I4, p.2। 2-220, 2005

GYENGE, J.; FERNÁNDEZ, M.E.; SCHLICHTER, T. Effects on site water balance of conversion from native mixed forest to Douglas-fir plantation in N.W. Patagonia. New Forests v.38, p.67-80, 2009.

IWAKIRI, S.; MONTEIRO DE MATOS, J.L.; PRATA, J.G.; TRIANOSKI, R.; SOARES DA SILVA, L. Evaluation of the use potential of nine species of Genus Eucalyptus for production of veneers and plywood panels. CERNE v.19, p. 263-269, 2013.

LICATA, J.A.; PYPKER, T.G.; WEIGANDT, M.; UNSWORTH, M.H., GYENGE, J.E.; FERNÁNDEZ, M.E.; SCHLICHTER, T.M.; BOND, B.J. Decreased Rainfall interception balances increased transpiration in exotic ponderosa plantations compared with native cypress stands in Patagonia, Argentina. Ecohydrology v.4 p.83-93, 201 I
LONG, J.N. A practical approach to density management. Forestry Chronicle v.23, p.23-27, 1985.

LONG, J.N.; DEAN, T.J.; ROBERTS, S.D. Linkages between silviculture and ecology: examination of several important conceptual models. For. Ecol. Manage. v.200, p.249-26I, 2004.

LONG, J.N.; VACCHIANO, G. A comprehensive framework of forest stand property-density relationships: perspectives for plant population ecology and forest management. Ann. For. Sci. v.7I, p. 325-335, 2014.

LUIS, J.F.S.; FONSECA, T.F. The allometric model in the stand density management if Pinus pinaster Ait. In Portugal. Ann. For. Sci. v.6I, p. 807-8I4, 2004.

MARANGON, G.P.; SCHNEIDER, P.R.; LORA ZIMMERMANN, A.P.; VILLANOVA LONGHI R.; CAVALLI, J.P. Density management diagrams for stands of Eucalyptus grandis $\mathrm{W}$. Hill RS, Brazil. Rev. Árvore v.4I, e410108, 2017.

MAYER, D.G; BUTLER, D.G. Statistical validation. Ecol Modell v.68, p. $21-32,1993$.

MENDONZA, L.A. Ensayos de procedencias de Eucalyptus camaldulensis Dehn. y E. viminalis Labill., en el norte de la provincia de Buenos Aires. IDIA Suplemento Forestal v.8, p.53-60, 1974.

MILIONE, G.M. Salinización y otros cambios hidrogeoquímicos asociados a distintos usos primarios del suelo en la región centro-sur bonaerense, Argentina. PhD Thesis, Universidad Nacional de La Plata. 2019. I36P.

MÓNACO, M.; LACLAU, P. Caracterización de la oferta de recursos forestales del partido de Balcarce, provincia de Buenos Aires. Rev. Inv. Agropecuaria RIA v.39, p. I49-161, 2013.

NEIVA, D.M.; ARAÚJO, S.; LOUENCO, A.; GOMINHO, J.; PEREIRA, H.A. Kraft pulping and wood chemical composition for 12 Eucalyptus species. In: 13th European Workshop on Lignocellulosics and pulp. Seville, Spain, 2014.

NETER, J,; WASERMAN, W. Applied linear statistical models. Regression analysis of variance and experimental design. R.D. Irwin Inc. Illinois, USA, 1974.

NEWTON, P.F. Stand density management diagrams: review of their development and utility in stand-level management planning. For. Ecol. Manage. v.98, p. 25I-265, 1997

NOSETTO, M.; JOBBÁGY, E.; TÓTH, T.; JACKSON, R. Regional patterns and controls of ecosystem salinization with grassland afforestation along a rainfall gradient. Global Biogechemical Cycles. 22 (2), art. no. GB20 I5, 2008.

PARUELO, J. M.; JOBBÁGY, E.; OESTERHELD, M.; GOLLUSCIO, R.A.; AGUIAR, M.R. Grasslandsand steppes of Patagonia and the Río de la Plata plains. Pages 232-248 in T. T. Veblen, K. R. Young, and A. R. Orme, editors. The physical geography of South America. Oxford University Press, Oxford, UK. 2007. 
PÉREZ, S.; RENEDO, C.J.; ORTIZ, A.; MAÑANA, M. Energy potential of waste from 10 forest species in the North of Spain (Cantabria). Bioresource Technology v.99, p. 63396345, 2008.

PÉREZ-CRUZADO, C.; MERINO, A.; RODRÍGUEZSOALLEIR,,,O, R. A management tool for estimating bioenergy production and carbon sequestration in Eucalyptus globulus and Eucalyptus nitens grown as short rotation woody crops in north-west Spain. Biom. Energy v.35, 2839e285I, 201 I.

REINEKE, L.H. Perfecting a stand-density index for even-aged forests. J. Agr. Res. v.46, p.627-638, 1933.

SCHARF, F.S.; JUANES, F; SUTHERLAND, M. Inferring ecological relationships from the edges of scatter diagrams: comparison of regression techniques. Ecology v.79, p. 448-460, 1998.

SCHNELL, S.; KLEINN, C.; ÁLVAREZ GONZÁLEZ, J.G. Stand density management diagrams for three exotic tree species in smallholder plantations in Vietnam. Small-scale v. I I, p. 509-528, 2012

SCHÖNAU, A.P.G.; COETZEE, J. Initial Spacing, stand density and thinning in Euclaypt plantations. For. Ecol. Manage. v.29, p. 245-266, 1989.
SINAVIMO Eucalyptus spp. Sistema Nacional Argentino de Vigilancia y Monitoreo de Plagas. SENASA, Ministerio de Agroindustria de la Nación Argentina. http://www.sinavimo. gov.ar/cultivo/eucalyptus-spp; last accessed I2 Apr., 2018.

TANG, X.; PÉREZ-CRUZADO, C.; VOR, T.; FEHRMANN, L.; ÁLVAREZ-GONZÁLEZ, J.G.; KLEINN, CH. Development of stand density management diagrams for Chinese fir plantations. Forestry v.89, p. 36-45, 2016.

VOSPERNIK, S.; STERBA, H. Do competition-density rule and self-thinning rule agree?. Ann For Sci v.72, p. 379$390,2015$.

VALBUENA, P.; DEL PESO, C.; BRAVO, F. Stand density management for two Mediterranean pine species in Eastern Spain. For. Syst. v. I 7, p. 97- 104, 2008.

WHITEHEAD, D.; BEADLE, CH.L. Physiological regulation of productivity and water use in Eucalyptus: a review. For. Ecol. Manage. v. I93, p. I I3-I40, 2004.

ZHANG L, BI H, GOVE JH, HEATH LS. 2005. A comparison of alternative methods for estimating the self-thinning boundary line. Can. J. For. Res. 35: I507-I 5 I4 